\title{
A Bi-Directional Isolated DC/DC Converter as a Core Circuit for 3.3-kV/6.6-kV Power Conversion Systems in the Next Generation
}

\author{
Shigenori Inoue Student Member (Tokyo Institute of Technology) \\ Hirofumi Akagi Member (Tokyo Institute of Technology)
}

Keywords: power conversion, high-frequency transformers, loss analysis, power semiconductor devices

The next-generation power switching device based on $\mathrm{SiC}$ and/or $\mathrm{GaN}$ is attractive as one of the most promising devices characterized by ultra-low conducting and switching losses. The $\mathrm{SiC}$ power switching devices will bring high power density to power conversion systems. However, a power conversion system requires a bulky and heavy line-frequency transformer to connect it to a mediumvoltage industrial or utility grid. The transformer would be an obstacle to achieve high power density even if the SiC-based switching devices were employed.

Figure 1 shows a bi-directional isolated $\mathrm{dc} / \mathrm{dc}$ converter, where electrical isolation is achieved by the $20-\mathrm{kHz}$ transformer. When it was presented in 1991, the conducting and switching losses of the first-generation IGBTs were so large that no attention has been paid to the $\mathrm{dc} / \mathrm{dc}$ converter as the core circuit of medium-voltage power conversion systems. However, the $\mathrm{dc} / \mathrm{dc}$ converter is becoming a strong candidate of the core circuit due recent advances in power device technologies.

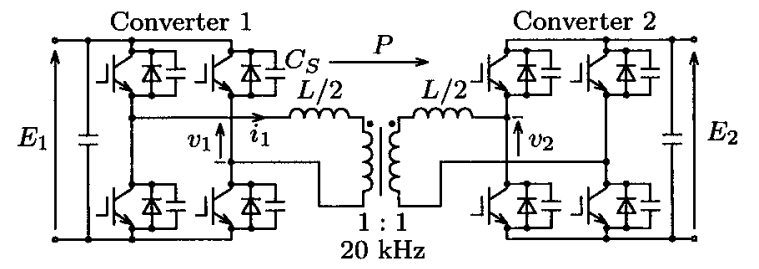

Fig. 1. The bi-directional isolated dc/dc converter

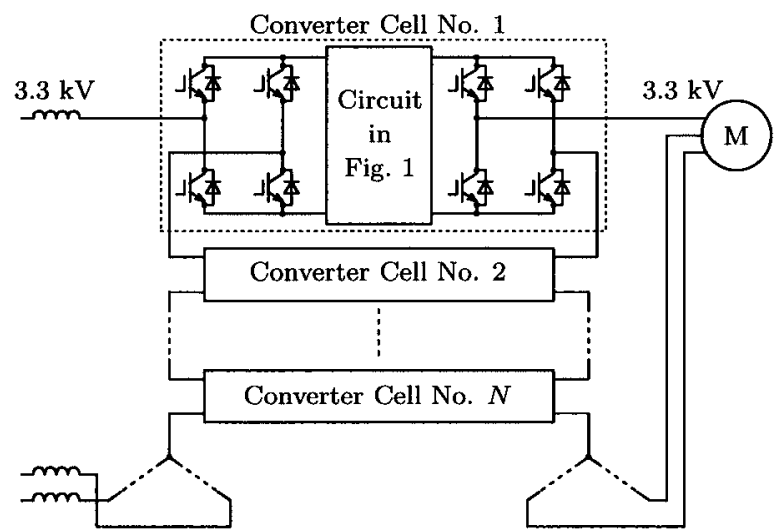

Fig. 2. A 3.3-kV direct motor drive system in the next generation
This paper proposes $3.3-\mathrm{V} / 6.6-\mathrm{kV}$ power conversion systems using the $\mathrm{dc} / \mathrm{dc}$ converter as the core circuit, and also designs and implements a $350-\mathrm{V}, 10-\mathrm{kW}$ bi-directional isolated dc/dc converter, using the fifth-generation $600-\mathrm{V} \mathrm{Si}$-IGBTs, instead of the $\mathrm{SiC}$ power devices. Figure 2 depicts one of the proposed power conversion systems, which is a $3.3-\mathrm{kV}$ motor drive system in the next generation. If the power rating of the $3.3-\mathrm{kV}$ motor drive system is $270 \mathrm{~kW}$ and $N=9$ in Fig. 2, the dc-link voltage of a single converter cell is $339 \mathrm{~V}$, and its power rating is $10 \mathrm{~kW}$. The efficiency from the dc input to the dc output of the dc/dc converter was accurately measured to be as high as $97 \%$, excluding the losses of the gate-drive and control circuits. A unique experimental circuit, in which the dc output terminals are connected back to the dc input terminals, makes it possible to achieve accurate measurement of the overall loss of the $\mathrm{dc} / \mathrm{dc}$ converter.

Loss analysis was carried out to estimate the effect of $\mathrm{SiC}$ power devices. The loss in the power devices was $279 \mathrm{~W}$, which was dominant in the overall loss. A $1.05-\mathrm{kV} \mathrm{SiC-MOSFET} \mathrm{announced} \mathrm{in}$ March 2005 has the world's lowest specific on-state resistance of $6 \mathrm{~m} \Omega$. It can be expected that the use of SiC MOSFET reduces the conducting loss is reduced to one-fifth, and the switching loss to one-tenth, in comparison to the use of the Si-IGBTs. In this case, the efficiency of the dc/dc converter can be improved from $97 \%$ to $99 \%$ or higher.

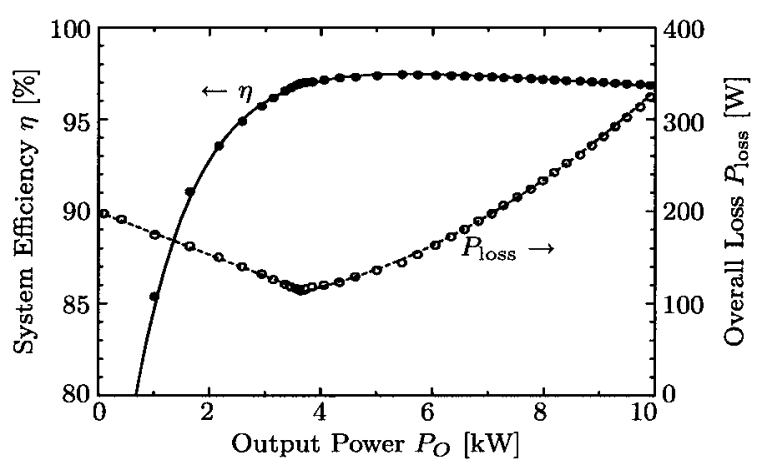

Fig. 3. Relationships among the output power $P_{O}$, the system efficiency $\eta$ and the overall loss $P_{\text {loss }}$

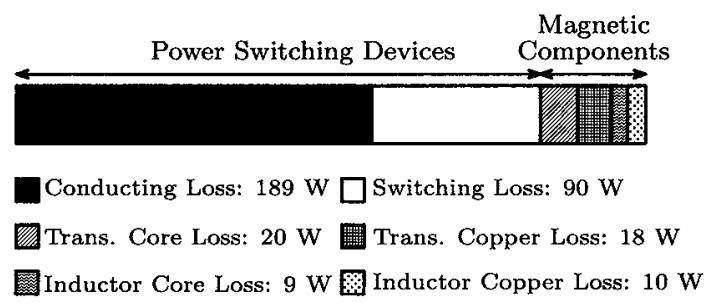

Fig. 4. Result of loss analysis in the experimental circuit 


\title{
次世代 $3.3 \mathrm{kV} / 6.6 \mathrm{kV}$ 電力変換システムのコア回路としての 双方向絶縁形DC/DC コンバータ
}

\author{
学生員 井上 重徳* 正 員 赤木 泰文* \\ A Bi-Directional Isolated DC/DC Converter as a Core Circuit \\ for 3.3-kV/6.6-kV Power Conversion Systems in the Next Generation \\ Shigenori Inoue*, Student Member, Hirofumi Akagi*, Member
}

\begin{abstract}
This paper describes a bi-directional isolated dc/dc converter considered as a core circuit of 3.3-kV/6.6-kV highpower-density power conversion systems in the next generation. The dc/dc converter is intended to use power switching devices based on $\mathrm{SiC}$ and/or GaN, which will be available on the market in the near future. A 350-V, 10-kW and $20 \mathrm{kHz}$ dc/dc converter is designed, constructed and tested in this paper. It consists of two single-phase full-bridge converters with the latest trench-gate Si-IGBTs and a $20-\mathrm{kHz}$ transformer with a nano-crystalline soft-magnetic material core and litz wires. The transformer plays an essential role in achieving galvanic isolation between the two full-bridge converters. The overall efficiency from the dc-input to dc-output terminals is accurately measured to be as high as $97 \%$, excluding gate drive circuit and control circuit losses from the whole loss. Moreover, loss analysis is carried out to estimate effectiveness in using SiC-based power switching devices. The loss analysis clarifies that the use of SiC-based power devices may bring a significant reduction in conducting and switching losses to the dc/dc converter. As a result, the overall efficiency may reach $99 \%$ or higher.
\end{abstract}

キーワード：電力変換, 高周波変圧器, 損失分析, パワー半導体デバイス

Keywords: power conversion, high-frequency transformers, loss analysis, power semiconductor devices

\section{1. まえがき}

シリコンカーバイド $(\mathrm{SiC})$ や窒化ガリウム $(\mathrm{GaN})$ に代 表されるワイドギャップ半導体は, シリコン $(\mathrm{Si})$ に比較し て優れた物性值を有しており，これらのワイドギャップ半導 体を用いた次世代の低損失・高速パワーデバイスの研究・開 発が活発に進められている ${ }^{(1) ~(6) 。 I n f i n e o n ~ T e c h n o l o g i e s ~}$ と Cree 社は 300/600/1,200 V の SiC-SBD (Schottky Barrier Diode）を既に市販しており，これを用いた電力变換装置の評 価実験も行われている (7)。また, SiCを使用したJFET (Junction Field-Effect Transistor)/SIT (Static-Induction Transistor) ${ }^{(3)}$, MOSFET (Metal-Oxide-Semiconductor Field-Effect Transistor) (4) などのスイッチングデバイスの研究・開発に ついても, 実験室レベルから製品化レベルへ移行しつつあ る。2004 年 12 月には三菱電機とロームが, さらに，2005 年 3 月には産業技術総合研究所がチャネル抵抗を低減した

\footnotetext{
* 東京工業大学 大学院理工学研究科 電気電子工学専攻

干152-8552 東京都目黒区大岡山 2-12-1, S3-17

Department of Electrical and Electronic Engineering, Tokyo Institute of Technology

S3-17, 2-12-1, O-okayama, Meguro, Tokyo, 152-8552 Japan
}

$1 \mathrm{kV}$ クラスの SiC-MOSFET を相次いで発表し, 製品化も 期待されている(4) (6)。

$\mathrm{SiC}$ パワーデバイスは現行の $\mathrm{Si}$ パワーデバイスに比較し て低損失であり，しかも高温動作が可能であるために放熱 フィンやファンなどの冷却装置を大幅に小形化できる。そ のため, $\mathrm{SiC}$ パワーデバイスは電力変換装置の電力密度向 上に大きく寄与すると考えられている。

しかし, 高圧電力系統に連系する電力変換装置において は, 電気的絶縁を図るための商用周波数变圧器 $(50 / 60 \mathrm{~Hz})$ の占める体積・重量の割合が大きい。このため, $\mathrm{SiC}$ パワー デバイスを用いても電力密度の向上には限界がある。

図 1 に示す双方向絶縁形 DC/DC コンバータは, 高周波 変圧器を用いて入出力間の電気的絶縁と昇降圧を行うこと のできる電力変換回路である。文献 (8), (9) が発表された 当時, 第 1 世代 IGBT (Insulated-Gate Bipolar Transistor) の導通損失とスイッチング損失はともに大きく, 高圧電力 変換システムのコア回路としての応用はまったく考慮され ていなかった。

本論文では， $6.6 \mathrm{kV}$ 配電系統に連系する電力変換装置と して, 図 1(a) に示す双方向絶縁形 DC/DC コンバータをコ ア回路として用いた回路方式を提案する ${ }^{(10)}$ 。また， $3.3 \mathrm{kV}$, 


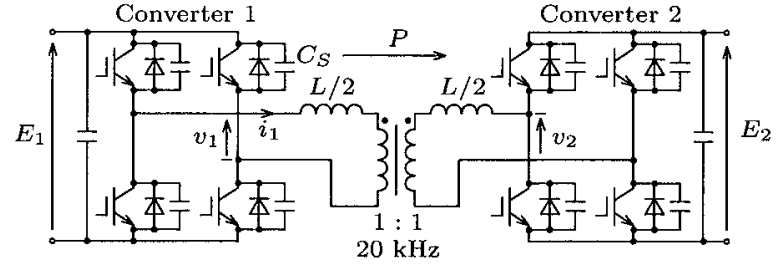

(a) Based on a non-resonant circuit.

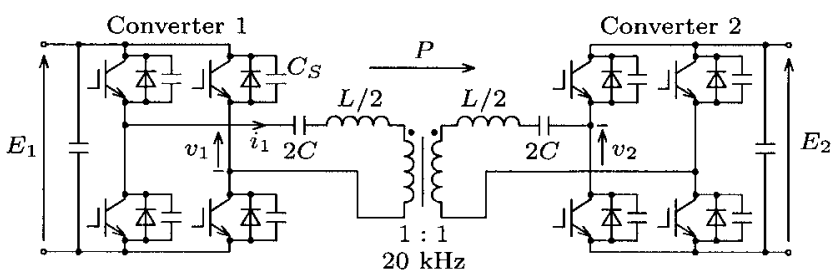

(b) Based on a series-resonant circuit.

図 1 双方向絶縁形 DC/DC コンバー夕

Fig. 1. The bi-directional isolated dc/dc converter.

$270 \mathrm{~kW}$ の高圧ダイレクトドライブシステムのコア回路と して，第 5 世代 Si-IGBT を用いた双方向絶縁形 DC/DC コ ンバータ $(350 \mathrm{~V}, 10 \mathrm{~kW}, 20 \mathrm{kHz})$ を設計・製作する。実 験回路（図 6）では，直流出力端を直流入力端に接続し，出 力電力を入力端に回生している。このような回路構成を採 用することによって，双方向絶縁形 DC/DC コンバータの 全損失を容易かつ正確に測定できる。この損失分析の結果 から $\mathrm{SiC}$ パワーデバイスを導入した場合の損失を予測する。 実験回路のシステム効率（直流入力 $\rightarrow$ 直流出力）は定格 $10 \mathrm{~kW}$ 出力時に $96.8 \%$, 最大 $97.4 \%\left(P_{O}=5.5 \mathrm{~kW}\right.$ の場合 $)$ であり，第 5 世代 Si-IGBTを SiC-MOSFET に置き換えた 場合，定格時の効率は $99 \%$ に達する可能性を示す。

\section{2. 現行の高圧電力変換回路とその技術課題}

$\langle 2 \cdot 1\rangle \quad 6.6 \mathrm{kV}$ 配電系統用 BTB システム図 2 に $6.6 \mathrm{kV}$ 配電系統用 BTB（Back-to-Back）システム $\dagger$ の回路 構成を示す ${ }^{(11)} 。 6.6 \mathrm{kV} ， 50 / 60 \mathrm{~Hz}$ の交流電圧を変圧器で降 圧し， 2 台の 2 レベルまたは 3 レベルの電圧形PWM 変換 器を背合わせ (=Back to Back) に接続して双方向電力变換 装置を構成する。ここで, 変圧器を設置する目的は

- 交流電圧の降圧・昇圧

- 変換器と配電系統との絶縁

である。変圧器を設置しているため，ループを構成する 2 つのフィーダ間を零相電流が循環することはない。しかし, $6.6 \mathrm{kV}, 1 \mathrm{MVA}$ の変圧器 $(50 / 60 \mathrm{~Hz})$ は $3,000 \sim 4,000 \mathrm{~kg}$ もの重量がある。

最新のパワーデバイス (GCT, IEGT/IGBT) を使用し, ト ランスレス BTB システムを構成することは原理的には可能 である。しかし, 同一の配電変圧器から給電されるフィー 多間にトランスレス BTB システムを設置する場合，各相の 連系リアクトルやフィーダインピーダンスにアンバランス が存在すると，零相電流の基本波電流がフィーダ間を循環

\footnotetext{
†文献(11)では「ループコントローラ」と呼ばれている。
}

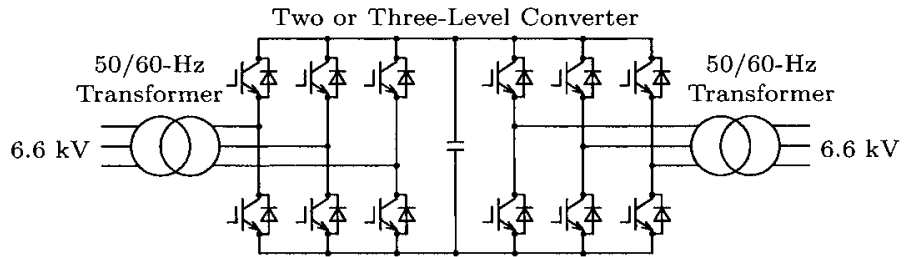

図 $26.6 \mathrm{kV}$ 配電系統用 BTB システム

Fig. 2. The present BTB system for the $6.6-\mathrm{kV}$ power distribution system.

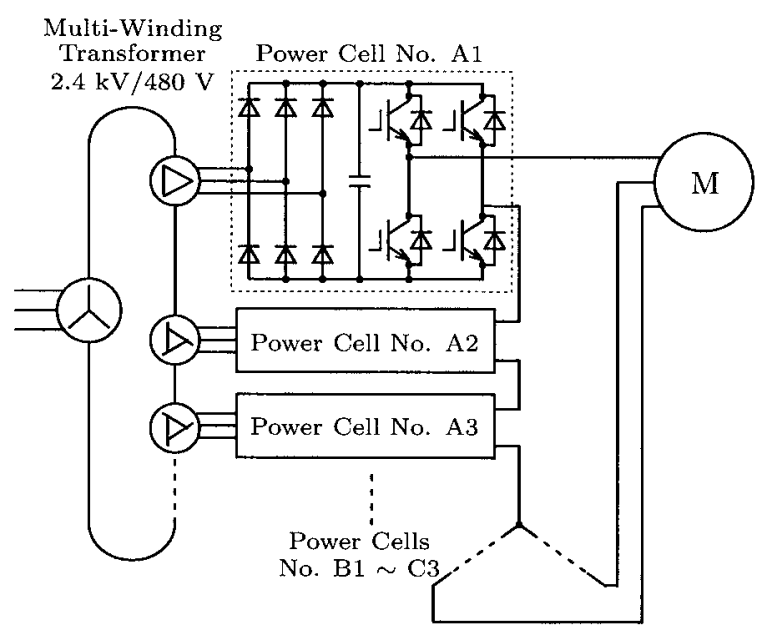

図 3 高圧ダイレクトドライブシステム ${ }^{(12)}$

Fig. 3. The present medium-voltage direct drive system (12).

し，地絡保護リレーの誤動作を引き起こす恐れがある。日 本の $6.6 \mathrm{kV}$ 非接地配電系統では, フィーダへ流出する零相 電流を $0.2 \mathrm{~A}$ 以下に抑制する必要がある。

$\langle\mathbf{2} \cdot \mathbf{2}\rangle$ 高圧ダイレクトドライブシステム 図 3 は, 米国 Robicon 社が世界で初めて開発・実用化した高圧交流 モータの可変速ドライブシステム ${ }^{(12)}$ であり, Robicon 方式 と呼ばれることもある。これは, 多巻線変圧器 $(50 / 60 \mathrm{~Hz})$ の 2 次側絶縁巻線に三相ダイオード整流回路とインバータ を接続し，3 台のインバータの交流出力端を直列に接続し て高圧交流モー夕への出力電圧の 1 相分とする回路構成に 特徵がある。高圧交流モー夕の印加電圧波形のレベル数は 7 であり, 高調波電圧を低減できる。さらに, 多巻線変圧 器の特殊な巻線構造によって高圧配電系統に流出する高調 波電流を低減している。この方式は，高圧ダイレクトドラ イブシステム全体に占める多巻線変圧器の重量・体積が大 きく，しかもモー夕減速時のエネルギーを電源へ回生する ことはできない。

\section{3. 提案する次世代高圧電力変換システム}

本章では, 高圧配電系統に接続される電力変換システム の小形・軽量化を目指して, 双方向絶縁形 DC/DC コンバー 夕をコア回路とする次世代高圧電力変換システムを提案す る(10)。 


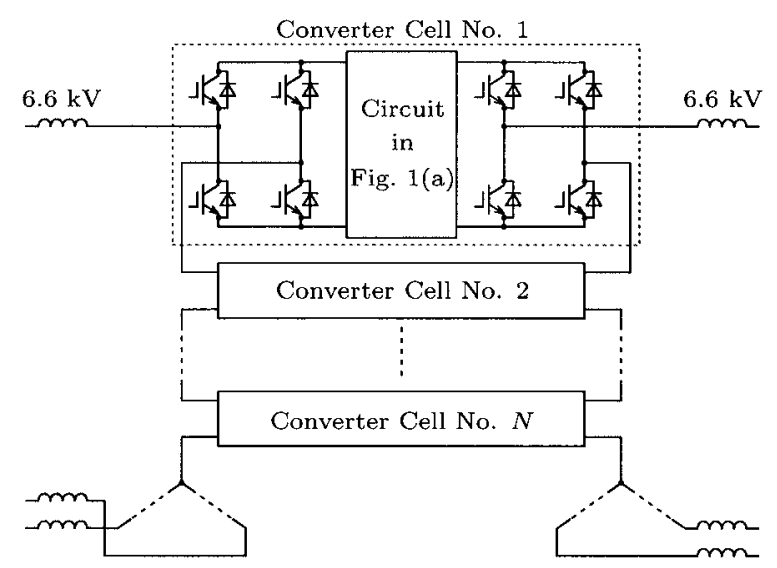

図 4 次世代 $6.6 \mathrm{kV}$ 配電系統用 BTB システム

Fig. 4. A 6.6-kV BTB system in the next generation.

表 1 次世代 $6.6 \mathrm{kV}$ 配電系統用 BTB システムに 使用するコンバータセルの設計例

Table 1. Design examples of the converter cell used for the next-generation BTB system for the $6.6-\mathrm{kV}$ power distribution system.

\begin{tabular}{c|c|c|c|c}
\hline \hline$N$ & Waveform & AC Input & DC Link & Device Rating \\
\hline 4 & 9 Level & $952 \mathrm{~V}$ & $1.52 \mathrm{kV}$ & $2.4 \mathrm{kV}$ \\
\hline 5 & 11 Level & $752 \mathrm{~V}$ & $1.22 \mathrm{kV}$ & $2.0 \mathrm{kV}$ \\
\hline 6 & 13 Level & $635 \mathrm{~V}$ & $1.02 \mathrm{kV}$ & $1.7 \mathrm{kV}$ \\
\hline 7 & 15 Level & $544 \mathrm{~V}$ & $870 \mathrm{~V}$ & $1.7 \mathrm{kV}$ \\
\hline 8 & 17 Level & $476 \mathrm{~V}$ & $762 \mathrm{~V}$ & $1.4 \mathrm{kV}$ \\
\hline 9 & 19 Level & $423 \mathrm{~V}$ & $677 \mathrm{~V}$ & $1.2 \mathrm{kV}$ \\
\hline
\end{tabular}

〈3・1 双方向絶縁形 DC/DC コンバータ 図 1 に双 方向絶縁形 DC/DC コンバー夕の回路方式を示す。(a) は非 共振形, (b) は共振形である。図 1(b) の共振形の回路では, 双方向絶縁形 DC/DC コンバータのスイッチング周波数を 共振周波数 $(=1 / 2 \pi \sqrt{L C})$ に設定することよって, 高周波 変圧器の印加電圧と巻線電流がほぼ正弦波になる。このた め, 双方向絶縁形 DC/DC コンバータ中のパワーデバイス はZCS（Zero-Current Switching）動作が可能となる。

本研究は $6.6 \mathrm{kV}$ 配電系統や $3.3 \mathrm{kV}$ 需要家系統に連系す る電力変換システムを対象としており，後述するように双 方向絶縁形 DC/DC コンバー夕の直流電圧は $1 \mathrm{kV}$ 以下であ る。図 1(a) と (b) を比較した場合, 図 1(b) では直列共振 コンデンサ $C$ の体積・重量は無視できず，非共振形である 図1(a)を用いるのが有利である。以降，図1(a)を用いた高 圧電力変換システムについて述べる。

$\langle\mathbf{3} \cdot 2\rangle$ 次世代 $6.6 \mathrm{kV}$ 配電系統用 BTB システム 図 4 に本研究で提案する次世代 $6.6 \mathrm{kV}$ 配電系統用 BTB システ ムを示す。各コンバータセルは, 双方向絶縁形 DC/DC コ ンバータとその入出力端に接続した単相フルブリッジ電圧 形 PWM 変換器とから構成されている。1 相あたり $N$ 台の コンバータセルをカスケード接続することによって，BTB システムを構成できる。

表 1 にコンバータセルの設計例を示す。コンバータセル の直流リンク電圧はそのカスケード接続数 $N$ に依存する。

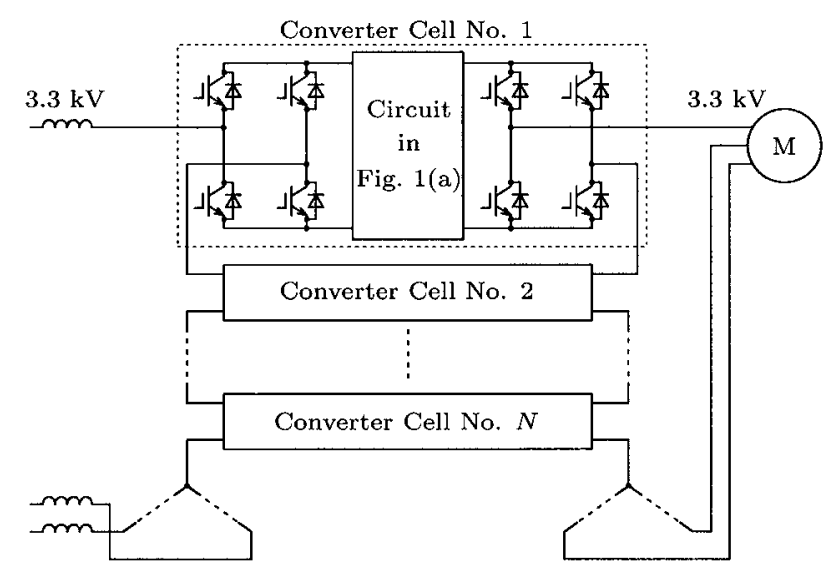

図 5 次世代 $3.3 \mathrm{kV}$ ダイレクトドライブシステム

Fig. 5. A 3.3-kV direct motor drive system in the next generation.

$N=9$ とすれば，コンバータセルの交流相電圧実効值は $6,600 / 9 \sqrt{3}=423 \mathrm{~V}$ となる。コンバータセルの直流リンク 電圧を $677 \mathrm{~V}^{\dagger}$ とすれば, $1.2 \mathrm{kV}$ IGBT を使用できる。この とき, 9 台のコンバータセルの交流端電圧波形のレベル数は 19 となり, 電圧形 PWM 変換器のキャリア周波数を $1 \mathrm{kHz}$ としても高調波の少ない良好な交流電圧波形を得られる。 したがって，スイッチングリプルは連系リアクトルのみで 完全に抑制でき，スイッチングリプル抑制フィルタを設置 する必要がない。また, 電圧形 PWM 変換器のスイッチン グ周波数は $1 \mathrm{kHz}$ であるため, スイッチング損失はほぼ無 視できる。

〈3.3〉 次世代高圧ダイレクトドライブシステム 図 5 に提案する次世代 $3.3 \mathrm{kV}$ ダイレクトドライブシステムを示 す。眓 4 と同様に,コンバータセルをカスケード接続し, 交流出力端に高圧交流モー夕を接続している。

$3.3 \mathrm{kV}$ ダイレクトドライブシステムの定格電力を $270 \mathrm{~kW}$ とし， $N=9$ とすれば，各コンバータセルの定格電力は $10 \mathrm{~kW}$ ，直流リンク電圧は $339 \mathrm{~V}$ となり，600Vの IGBTを 使用できる。本論文では次章以降, $3.3 \mathrm{kV}$ ダイレクトドラ イブシステムのコア回路として, 第 5 世代 Si-IGBT $(600 \mathrm{~V}$, $150 \mathrm{~A}$ ）を用いた双方向絶縁形 DC/DC コンバータ（350 V, $10 \mathrm{~kW}, 20 \mathrm{kHz})$ の設計・製作を行い，損失分析の結果か ら $\mathrm{SiC}$ パワーデバイスによる損失低減効果を予測する。

\section{4. コア回路の設計と特性}

$\langle 4 \cdot 1\rangle$ 回路構成図 6 に双方向絶縁形 DC/DC コン バー夕 $(350 \mathrm{~V}, 10 \mathrm{~kW}, 20 \mathrm{kHz})$ の実験回路構成を, 表 2 に回路定数を示す。また, 図 7 は使用した高周波変圧器の 写真である。2 台の単相フルブリッジ電圧形変換器（変換 器 1，2）が高周波変圧器を介して対称に接続されており, さらに出力電力 $P_{O}$ を直流電源 $E$ に回生している。このた め, 回路の全損失 $P_{\text {loss }}$ は直流電源 $E$ の出力電力として容 易かつ高精度に測定できる。実験では $P_{\text {loss }}$ をデイジタルパ

\footnotetext{
$\dagger 423^{\mathrm{V}} \times 1.6=677 \mathrm{~V}$
} 


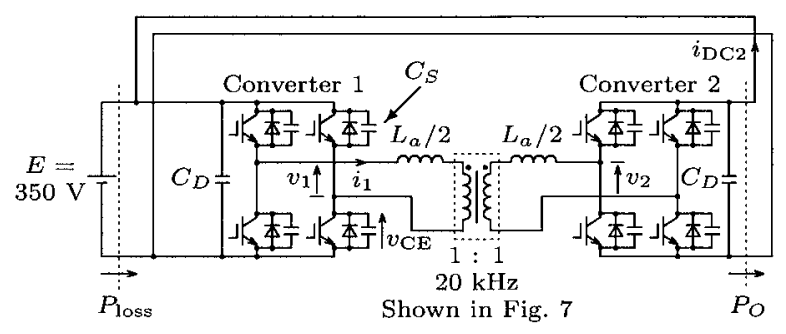

困 6 実験回路

Fig. 6. The experimental circuit configuration.

表 2 図 6 の回路定数

Table 2. Circuit parameters in Fig. 6.

\begin{tabular}{lc|r}
\hline \hline DC power supply voltage & $E$ & $350 \mathrm{~V}$ \\
\hline Rated power & $P$ & $10 \mathrm{~kW}$ \\
\hline DC capacitor & $C_{D}$ & $2,000 \mu \mathrm{F}$ \\
\hline Snubber capacitor & $C_{S}$ & $0.01 \mu \mathrm{F}(1.5 \%)$ \\
\hline Inductor & $L_{a} / 2$ & $10.5 \mu \mathrm{H}(11 \%)$ \\
\hline Inductor resistance & $R_{a} / 2$ & $4.5 \mathrm{~m} \Omega(0.037 \%)$ \\
\hline Transformer core material & & $\mathrm{FT}-3 \mathrm{M}$ \\
\hline Transformer turn number & & $17: 17$ \\
\hline Transformer leakage inductance & $L_{\text {trans }}$ & $1.6 \mu \mathrm{H}(1.6 \%)$ \\
\hline Transformer winding resistance & $R_{\text {trans }}$ & $17 \mathrm{~m} \Omega(0.14 \%)$ \\
\hline
\end{tabular}

On a single-phase $350-\mathrm{V}, 10-\mathrm{kW}, 20-\mathrm{kHz}$ base.

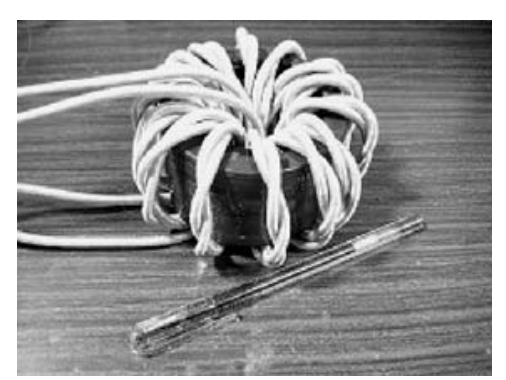

図 7 高周波変圧器 $(350 \mathrm{~V}, 10 \mathrm{kVA}, 20 \mathrm{kHz})$

Fig. 7. The 350-V, 10-kVA and 20-kHz transformer.

ワーメータ（横河電機 WT130）を用いて実測した。また， 直流電流計（横河電機 201137 ) を用いて出力直流電流 $i_{\mathrm{DC} 2}$ の平均值 $I_{\mathrm{DC} 2}$ を測定し, 出力電力 $P_{O}=E \cdot I_{\mathrm{DC} 2}$ とした。

変換器 1,2 には最新の第 5 世代 IGBT (三菱電機 CM200DY-12NF）を用いた。また, 高周波変圧器の磁性材 料は日立金属ファインメットFT-3M であり，巻線にはリッ ツ線を用いて表皮効果の影響を低減している。また，フェラ イトコア (TDK, PC44PQ50/50Z-12) とリッツ線 (6 turns) を用いた外付けのインダクタ 2 台 $\left(L_{a}=21 \mu \mathrm{H}\right)$ を接続し, 電 力伝送に関係するインダクタンス $L=L_{\mathrm{trans}}+L_{a}=22.6 \mu \mathrm{H}$ となるように調整している。高周波変圧器と外付けインダ ク夕の巻線抵抗 $R=R_{\text {trans }}+R_{a}=26 \mathrm{~m} \Omega$ である†。

パワーデバイスや高周波変圧器, 外付けインダク夕がす べて理想的である場合，変換器 1,2 の交流端の電圧 $v_{1}, v_{2}$ は $f=20 \mathrm{kHz}, 180^{\circ}$ 通流の矩形波電圧であり, 出力電力 $P_{O}$

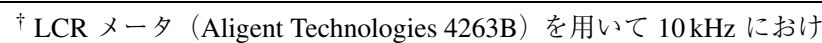
る $L_{\text {trans }}, L_{a}, R_{\text {trans }}, R_{a}$ を個別に測定した。

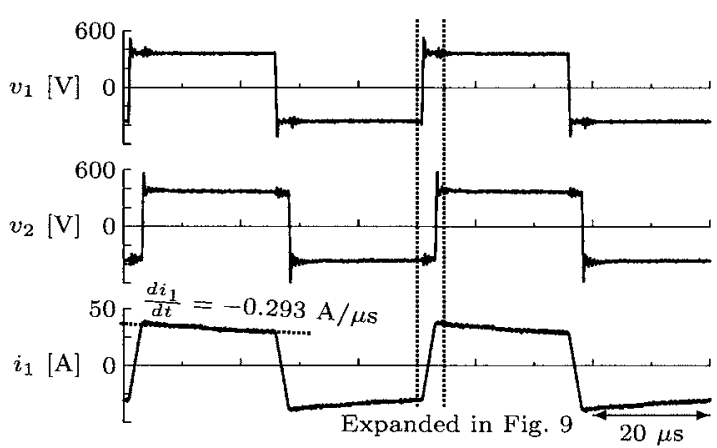

図 $810 \mathrm{~kW}$ 伝送時の実験波形

Fig. 8. Experimental waveforms when a power of $10 \mathrm{~kW}$ is delivered.

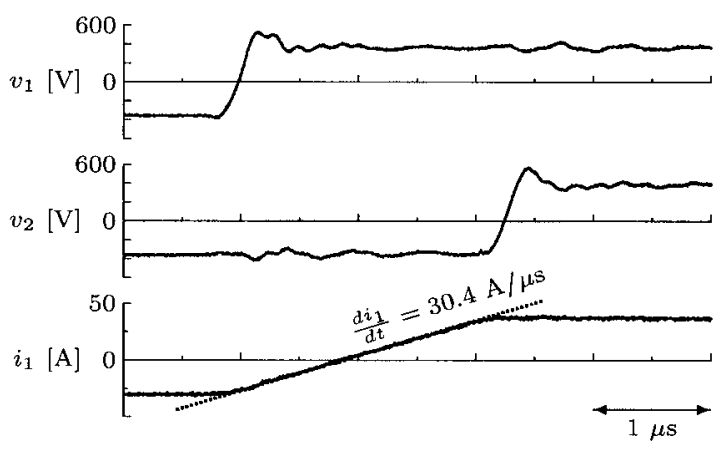

図 9 図 8 の時間拡大波形

Fig. 9. Time-expanded waveforms of Fig. 8.

はその位相差 $\delta[\mathrm{rad}]$ によって次式のように決定される ${ }^{(8)}$ 。 ここで, $\omega=2 \pi f$ である。

$$
P=\frac{E^{2}}{\omega L}\left(\delta-\frac{\delta^{2}}{\pi}\right) \text {. }
$$

図 6 では, IGBT と並列にスナバコンデンサ $C_{S}$ を接続 することによって, ZVS (Zero-Voltage Switching) を実現 している。ZVS が可能となるスイッチング時の電流最小值 $I_{\min }$ は漏れインダクタンス $L$ とスナバコンデンサ $C_{S}$ で決 定され，次式で表わされる(9)。

$$
I_{\min }=\frac{2 E}{\sqrt{L / C_{S}}} .
$$

$\langle\mathbf{4} \cdot \mathbf{2}\rangle$ 変換効率と損失 図 8 に出力電力 $P_{O}=10 \mathrm{~kW}$ における実験波形を, 図 9 にその拡大波形を示す。この動作 条件は位相差 $\delta=17^{\circ}$ であり, 電流 $i_{1}$ の実効值 $I_{1}=32.6 \mathrm{~A}$, 絶対值の平均值 $\left\langle\left|i_{1}\right|\right\rangle=32.0 \mathrm{~A}$ であった。また, 回路の全損 失 $P_{\text {loss }}=335 \mathrm{~W}$ であり, システム効率 $\eta=P_{O} /\left(P_{O}+P_{\text {loss }}\right)=$ 96.8\%であったけ†。図 8 , 図 9 中に示した $d i_{1} / d t$ の值は, 後 述する損失分析に用いるものである。

図 10 に出力電力 $P_{O}$ とシステム効率 $\eta$, 全損失 $P_{\mathrm{loss}}$ の 関係を示す。 $P_{\text {loss }}$ は $P_{O}=3.8 \mathrm{~kW}$ 付近で最小值をとる。

†このとき, 8 個の IGBT を駆動するゲート駆動回路の損失は $8.9 \mathrm{~W}$

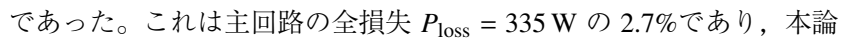
文では主回路の損失・効率についてのみ考察する。 


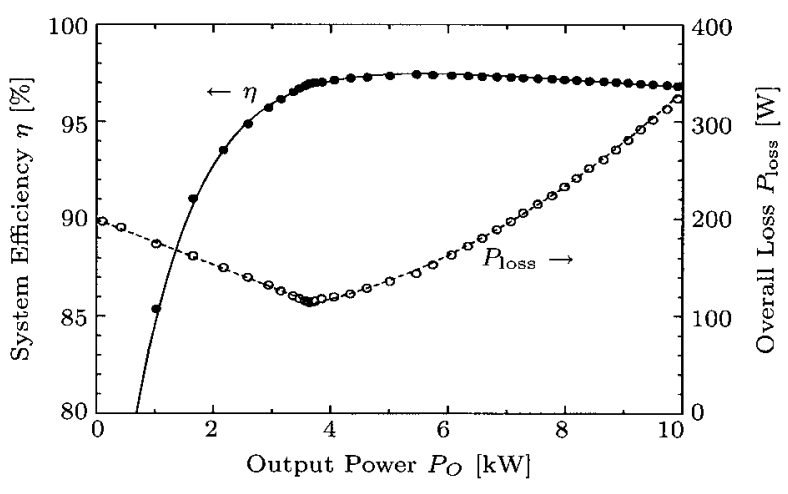

図 10 出力電力 $P_{O}$ とシステム効率 $\eta$, 全損失 $P_{\text {loss }}$ の関係

Fig. 10. Relationships among the output power $P_{O}$, the system efficiency $\eta$ and the overall loss $P_{\text {loss }}$.

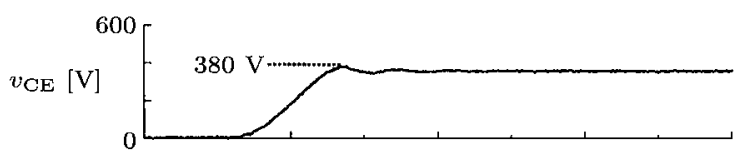

(a) When $P_{O}=0 \mathrm{~kW}$.

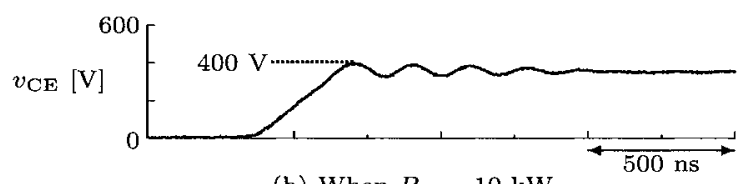

(b) When $P_{O}=10 \mathrm{~kW}$.

図 11 IGBT のコレクタ・エミッタ間電圧の波形

Fig. 11. Waveforms of the collector-emitter voltage of the IGBT.

$P_{O}<3.8 \mathrm{~kW}$ では ZVS が不完全となり，スナバ短絡が発生 し, スイッチング損失が支配的となる。一方, $P_{O}>3.8 \mathrm{~kW}$ ではIGBT の導通損失が支配的となる。 $P_{O}=5.5 \mathrm{~kW}$ のと き, $P_{\text {loss }}=144 \mathrm{~W}$ となり, システム効率 $\eta$ は最大值 $97.4 \%$ と なった。

$\langle\mathbf{4} \cdot \mathbf{3}\rangle$ IGBT のサージ電圧 図 11 は, 変換器 1 の下 側 IGBT のコレクタ・エミッタ間電圧 $v_{\mathrm{CE}}$ のターンオフ時 波形である。図 11(a) は出力電力 $P_{O}=0 \mathrm{~kW}$ における，ま た, (b) は出力電力 $P_{O}=10 \mathrm{~kW}$ における $v_{\mathrm{CE}}$ の波形であ る。スナバコンデンサ $C_{S}$ を IGBT のコレクタとエミッタ に最短に接続し, かつ IGBT のゲート抵抗を最適化するこ とによって, $v_{\mathrm{CE}}$ のサージ電圧最大值は, $380 \mathrm{~V}\left(P_{O}=0 \mathrm{~kW}\right.$ の場合)，400 V ( $P_{O}=10 \mathrm{~kW}$ の場合）に抑制できた。

$\langle\mathbf{4} \cdot \mathbf{4}\rangle \quad P_{O}=0 \mathrm{~kW}$ における損失 出力電力 $P_{O}=$ $0 \mathrm{~kW}$ の場合, コンデンサ $C_{S}$ の蓄積エネルギーは, すべて IGBT のターンオン時の損失となる。図 6 の $C_{S}$ に関する 全損失 $P_{\text {snub }}$ は理論的に次式で表わされる。

$$
\begin{aligned}
P_{\text {snub }} & =8 C_{S} E^{2} f \\
& =8 \times 0.01 \mu \mathrm{F} \times(350 \mathrm{~V})^{2} \times 20 \mathrm{kHz} \\
& =196 \mathrm{~W} \ldots \ldots \ldots \ldots \ldots \ldots \ldots \ldots \ldots
\end{aligned}
$$

$\langle 5 \cdot 2\rangle$ 節で述べるように, 高周波変圧器の鉄損は $P_{\text {core,tr }}=$ $20 \mathrm{~W}$ と推定できる。したがって， $P_{O}=0 \mathrm{~kW}$ における

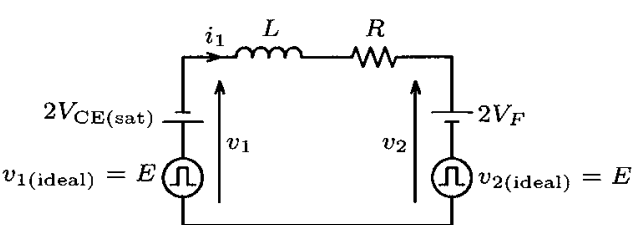

困 12 変圧器と外付けインダクタの巻線抵抗 $R$ とパワーデバイスの電圧降下を考慮した図 6 の等 価回路

Fig. 12. Equivalent circuit of Fig. 6 where the winding resistance $R$ of the transformer and the inductors, and the voltage drop across the power devices are taken into account.

$\mathrm{DC} / \mathrm{DC}$ コンバータの全損失の理論值は $P_{\text {snub }}+P_{\text {core,tr }}=$

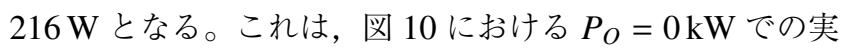
測結果 $P_{\text {loss }}=197 \mathrm{~W}$ にほぼ一致する。

\section{5. 損失分析}

〈5・1〉 パワーデバイスの導通損失 図 8 , 図 9 の $d i_{1} / d t$ の值から, $P_{O}=10 \mathrm{~kW}$ の場合のパワーデバイス $($ IGBT $\times 2$, Diode $\times 2)$ の電圧降下 $2\left(V_{\mathrm{CE}(\mathrm{sat})}+V_{F}\right)$ を推定でき

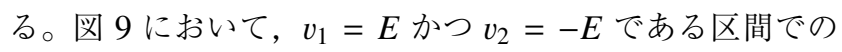
$d i_{1} / d t=30.4 \mathrm{~A} / \mu \mathrm{s}$ であり, 次式が成立する。

$$
L \frac{d i_{1}}{d t}=2 E-R i_{1}
$$

ここで, 上式右辺第 2 項は第 1 項 $(=700 \mathrm{~V})$ に比較して十分 小さいために無視でき, $L=23.0 \mu \mathrm{H}$ が得られる。以下の損 失分析では, $\langle 4 \cdot 1\rangle$ 節の $L=22.6 \mu \mathrm{H}$ ではなく, $L=23.0 \mu \mathrm{H}$ を用いる。

図 8 において $v_{1}=v_{2}=E$ となる区間では, 図 6 は図 12 に示す等価回路で表わすことができる。ただし, 図 12 は 高周波変圧器と外付けインダク夕の巻線抵抗 $R$ とパワーデ バイスの電圧降下を考慮している。また, $v_{1 \text { (ideal) }}$ と $v_{2 \text { (ideal) }}$ はパワーデバイスが理想的である場合の $v_{1}$ と $v_{2}$ である。 図 8 において $d i_{1} / d t=-0.293 \mathrm{~A} / \mu \mathrm{s}$ であり,これを用いて パワーデバイスの電圧降下の合計值 $2\left(V_{\mathrm{CE}(\mathrm{sat})}+V_{F}\right)$ を次式 のように推定できる。

$$
2\left(V_{\mathrm{CE}(\mathrm{sat})}+V_{F}\right)=-L \frac{d i_{1}}{d t}-R i_{1}=5.9 \mathrm{~V} \cdot
$$

ここで，上式中の $i_{1}$ を絶対值の平均值 $\left\langle\left|i_{1}\right|\right\rangle て ゙$ 近似すると, パワーデバイスの導通損失を次式のように推定できる。

$$
P_{\text {cond }}=2\left(V_{\mathrm{CE}(\mathrm{sat})}+V_{F}\right) \cdot\left\langle\left|i_{1}\right|\right\rangle=189 \mathrm{~W} \cdots
$$

$\langle\mathbf{5} \cdot \mathbf{2}\rangle$ 高周波変圧器と外付けインダクタの損失 表 3 に高周波変圧器と外付けインダクタの特性と鉄損, 銅損 $\left(P_{O}=10 \mathrm{~kW}\right.$ の場合) を示す。高周波変圧器の場合, 鉄 心の有効断面積 $\left(A_{e}=300 \mathrm{~mm}^{2}\right)$, 巻数 (17 turns), 電圧 $(E=350 \mathrm{~V})$, スイッチング周波数 $(f=20 \mathrm{kHz})$ が既知 であるために, 鉄心内の最大磁束密度 $B_{\max , \mathrm{tr}}=0.86 \mathrm{~T}$ と 計算できる。外付けインダクタの場合には電流 $i_{1}$ の実効值 
表 3 変圧器と外付けインダク夕の特性と定格時

$(10 \mathrm{~kW})$ の損失

Table 3. Characteristics and the loss of the transformer and the inductors at the rated power of $10 \mathrm{~kW}$.

\begin{tabular}{c|c|c}
\hline \hline Parameter & Transformer & Inductor \\
\hline Core Material & Finemet FT-3M & Ferrite PC44 \\
\hline Effective Cross Section & $300 \mathrm{~mm}^{2}$ & $328 \mathrm{~mm}^{2}$ \\
\hline Effective Volume & $60.7 \mathrm{~cm}^{3}$ & $37.2 \mathrm{~cm}^{3}$ \\
\hline Turn Number & $17: 17$ & 6 \\
\hline Maxium Flux Density & $0.86 \mathrm{~T}$ & $0.17 \mathrm{~T}$ \\
\hline Winding Resistance & $17 \mathrm{~m} \Omega$ & $4.5 \mathrm{~m} \Omega$ \\
\hline Core Loss $P_{\text {core }}$ & $20 \mathrm{~W}$ & $4.5 \mathrm{~W}$ \\
\hline Copper Loss $P_{\text {copp }}$ & $18 \mathrm{~W}$ & $4.8 \mathrm{~W}$ \\
\hline The core losses were calculated based on the datasheets. \\
Two inductors were used in the experimental circuit.
\end{tabular}

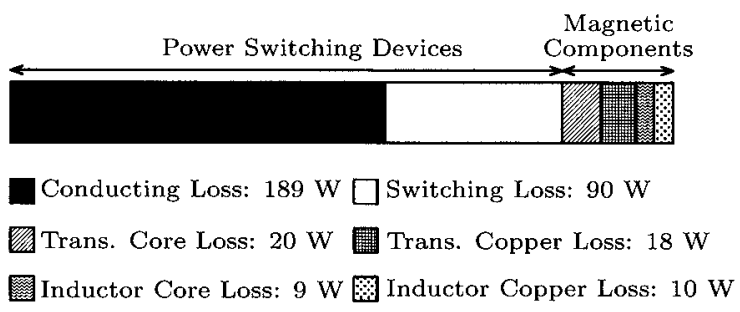

図 13 損失分析結果

Fig. 13. Result of loss analysis in the experimental circuit.

$I_{1}=32.6 \mathrm{~A}$ を使用して最大磁束密度 $B_{\text {max,ind }}=0.174 \mathrm{~T}$ と計算した。最大磁束密度 $B_{\max }$ とスイッチング周波数 $f=20 \mathrm{kHz}$ から，データシートを用いて鉄損を推定でき る。表 3 に示すように, 出力電力 $P_{O}=10 \mathrm{~kW}$ の場合, 高 周波変圧器の鉄損 $P_{\text {core,tr }}=20 \mathrm{~W}$, 外付けインダクタの鉄 損 $P_{\text {core, ind }}=4.5 \mathrm{~W} \times 2$ 台 $=9.0 \mathrm{~W}$ であった 。

高周波変圧器の巻線抵抗 $R_{\text {trans }}=17 \mathrm{~m} \Omega$ であり, 電流 $i_{1}$ の実効值は $I_{1}=32.6 \mathrm{~A}$ であるために, 高周波変圧器の銅損 $P_{\text {cond,tr }}=17 \mathrm{~m} \Omega \times(32.6 \mathrm{~A})^{2}=18 \mathrm{~W}$ と計算できる。同様に, 外付けインダクタの銅損は $P_{\text {cond,ind }}=4.5 \mathrm{~m} \Omega \times(32.6 \mathrm{~A})^{2} \times 2$ 台 $=9.6 \mathrm{~W}$ である。

$\langle\mathbf{5} \cdot 3\rangle$ 損失分析結果 図 13 に損失分析結果を示す。 図中のスイッチング損失 $P_{\mathrm{sw}}$ は, 全損失 $P_{\mathrm{loss}}=335 \mathrm{~W}$ か ら, 以上で得られたパワーデバイスの導通損失と変圧器と インダクタの損失を差し引いて求めた。したがって, 図 13 中のスイッチング損失 $P_{\mathrm{sw}}$ はスイッチング損失以外の損失 を含んでいる可能性があるが，スイッチング損失が支配的 であると考えられる。

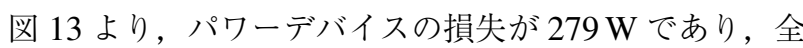
損失 $335 \mathrm{~W}$ に対して最も支配的である。したがって，本論 文の実験回路に使用した第 5 世代 IGBT を $\mathrm{SiC}$ パワーデバ イスに置き換えることによって，大幅な損失低減が期待で きる。

†高周波変圧器には矩形波電圧が印加されるために鉄心内の磁束密 度は三角波となる。一方, 外付けインダクタには台形波状の電流が流 れるため，鉄心内の磁束密度も台形波状になる。簡単のため， $20 \mathrm{kHz}$ 基本波（正弦波）磁束密度による鉄損のみを考慮している。

\section{6. $\mathrm{SiC}$ パワーデバイスによる損失低減効果}

〈6・1〉 $\mathrm{SiC}$ パワーデバイスの研究・開発動向 $\mathrm{SiC}$ は 絶縁破壞電界が $\mathrm{Si}$ の 10 倍であり, 高耐圧・低損失・高速 ユニポーラデバイスを実現できる。 $1.2 \mathrm{kV}$ MOSFET のド リフト層のオン抵抗 (specific on-state resistance) $\left[\mathrm{m} \Omega \mathrm{cm}^{2}\right]$ の理論限界は, $\mathrm{Si}$ を用いた場合には $135 \mathrm{~m} \Omega \mathrm{cm}^{2}$ となるが, $\mathrm{SiC}$ を用いれば $0.248 \mathrm{~m} \Omega \mathrm{cm}^{2}$ まで低減される(1)。しかし, SiC-MOSFET の場合にはチャネル移動度が低いためにチャ ネル抵抗が支配的となる。このため, チャネル移動度がド リフト層の移動度と等しい JFET の研究も行われている。

文献 (3) では, SiC-JFET $\left(600 \mathrm{~V}, 25 \mathrm{~A}, 2.94 \mathrm{~m} \Omega \mathrm{cm}^{2}\right)$ 计と SiC-SBD を用いたモー夕駆動用インバータを製作し, JFET のオン電圧が $38 \mathrm{~m} \Omega \times 20 \mathrm{~A}=0.76 \mathrm{~V}$ であることを報告し ている。これは, 本論文の実験に使用した Si-IGBT のオン 電圧の $1 / 2$ 以下の值である。なお，この SiC-JFET はノー マリオン形のデバイスである。

文献(1) は $600 \mathrm{~V}$ 耐圧の Si-IGBT と SiC-MOSFET にお ける導通損失とスイッチング損失を比較して抢り, $\mathrm{SiC}$ MOSFET の導通損失とスイッチング損失が共に $1 / 10$ に 低減できると予測している。2004 年 12 月には, チャネル 抵抗を低減する最新技術を駆使して, 三菱電機は $1.2 \mathrm{kV}$, $12.9 \mathrm{~m} \Omega \mathrm{cm}^{2}$, ロームは $1 \mathrm{kV}, 7.15 \mathrm{~m} \Omega \mathrm{cm}^{2}$ の SiC-MOSFET を発表した ${ }^{(5)}$ 。さらに, 2005 年 3 月には産業技術総合研究 所が $1.1 \mathrm{kV}, 4.3 \mathrm{~m} \Omega \mathrm{cm}^{2}$ の SiC-MOSFET を発表した ${ }^{(6)}$ 。 $1.2 \mathrm{kV} \mathrm{Si-IGBT}$ に比較して, 導通損失を $1 / 2 \sim 1 / 5$ 程度に 低減できる。

$\langle 6 \cdot 2\rangle \mathrm{SiC}-\mathrm{MOSFET}$ と SiC-SBD を使用した場合の効 率予測図 6 の第 5 世代 Si-IGBT を SiC-MOSFET に置 き換えることで, 送電側の変換器の導通損失は $1 / 2 \sim 1 / 5$ 程度に低減できると予測できる。また，ダイオードに SiCSBD を使用すれば，スイッチングデバイスとダイオードが 共にユニポーラデバイスであるために，スイッチング損失 を大幅に低減できると考えられる。

受電側変換器では，電流は主にダイオードを流れる。現 在, Infineon Technologies 社が製品化した SiC-SBD $(600 \mathrm{~V}$, $6 \mathrm{~A})$ の順電圧降下は $1.5 \sim 2.1 \mathrm{~V}$ であり，これは上述した SiC-MOSFET のオン時の電圧降下に比較してはるかに大 きい。しかし，スイッチングデバイスに SiC-MOSFET を 使用する場合には同期整流を採用できる可能性があり, 受 電側変換器の導通損失を送電側変換器と同程度まで低減で きる。

以上の議論から, 実験回路において導通損失 $P_{\text {cond }}$ を $1 / 5$, スイッチング損失 $P_{\mathrm{sw}}$ を $1 / 10$ に低減できると仮定 すると, 図 13 より, 定格 $10 \mathrm{~kW}$ 伝送時に扔いて全損失 $P_{\text {loss }}=104 \mathrm{~W}$, システム効率 $\eta=99 \%$ に達すると予測で きる。図 5 の $3.3 \mathrm{kV}$ ダイレクトドライブシステムでは, 単 相電圧形 PWM 变換器のスイッチング周波数は $1 \mathrm{kHz}$ 程度

\footnotetext{
${ }^{\dagger \dagger} 0.02 \mathrm{~cm}^{2}$ のチップを 4 並列にして定格電流を $25 \mathrm{~A}$ としている。
} 
で十分であり，双方向絶縁形 DC/DC コンバー夕 $(20 \mathrm{kHz})$ に比較してスイッチング損失は無視できる。したがって, SiC-MOSFET/SiC-SBD を使用した単相電圧形 PWM 変換 器の効率は 99.5\%以上に達すると予測できる。この場合, コンバータセルの効率, すなわち, $3.3 \mathrm{kV}$ ダイレクトドライ ブシステムの電力変換効率は, $99.5 \% \times 99 \% \times 99.5 \%=98 \%$ となる。

\section{7. まとめ}

本論文では, 商用周波数変圧器を使用する現行の高圧電 力变換システムにおける技術課題を明らかにし, $\mathrm{SiC}$ パワー デバイスの使用を前提とした次世代 $3.3 \mathrm{kV} / 6.6 \mathrm{kV}$ 電力変換 システムを提案した。これは, 双方向絶縁形 DC/DC コン バー夕を用いて電気的絶縁を行う点に特長があり, 現行の 回路方式に比較して大幅な小形・軽量化が期待できる。さ らに本論文では, $3.3 \mathrm{kV}, 270 \mathrm{~kW}$ ダイレクトドライブシス テムのコア回路として, 双方向絶縁形 DC/DC コンバー夕 $(350 \mathrm{~V}, 10 \mathrm{~kW}, 20 \mathrm{kHz})$ を設計・製作し，損失分析を行っ た。さらに，損失分析の結果から， $\mathrm{SiC}$ パワーデバイスを 使用した場合には，双方向絶縁形 DC/DC コンバータの効 率は $99 \%, 3.3 \mathrm{kV}, 270 \mathrm{~kW}$ ダイレクトドライブシステム の効率は $98 \%$ に達すると予測した。

(平成 16 年 8 月 23 日受付, 平成 17 年 10 月 4 日再受付)

\section{文献}

（1）荒井和雄・吉田貞史： $\mathrm{SiC}$ 素子の基礎と応用, オーム社 (2003)

(2) J.A. Cooper, JR. and A. Agarwal: "SiC power-switching devices-The second electronics revolution?", Proc. of IEEE, Vol.90, No.6, pp.956-968 (2002)

(3) H.-R. Chang, E. Hanna, and A.V. Radun: "Development and demonstration of silicon carbide ( $\mathrm{SiC}$ ) motor drive inverter modules", IEEE PESC'03, Vol . 1, pp.211-216 (2003)

(4) G. Majumdar: "The status quo and future trends of power devices", The Paper of Technical Meeting on Semiconductor Power Converter, IEEJ, SPC05-01, pp.1-6 (2005)

(5) M. Kawai and C. Horikiri: "The invisible strength of power control semiconductors", Nikkei Electronics, 2005.2.14, No.893, pp.79-97 (2005) 河合基伸・堀切近史：「見えざる力パワー半導体」, 日経エレクトロ ニクス, 2005 年 2 月 14 日号, No.893, pp.79-97 (2005)

(6) S. Harada, M. Kato, M. Okamoto, T. Yatsuo, K. Fukuda, and K. Arai: " $4.3 \mathrm{~m} \Omega \mathrm{cm}^{2}, 1100 \mathrm{~V}$ normally-off IE-MOSFET on SiC", The Paper of Joint Technical Meeting on Electron Devices and Semiconductor Power Converter, IEE Japan, EDD-05-49/SPC-05-74, pp.27-31 (2005) (in Japanese) 原田信介・加藤 真 · 岡本光央 -八尾 勉 $\cdot$ 福田憲司 $\cdot$ 荒井和雄 : $\left\lceil 4.3 \mathrm{~m} \Omega \mathrm{cm}^{2}, 1100 \mathrm{~V}\right.$ ノーマリオフ $\mathrm{SiC}$ IE-MOSFET $\rfloor$, 電気学会電子 デバイス・半導体電力変換合同研資, EDD-05-49/SPC-05-74, pp.27-31 (2005)

(7) G. Spiazzi, S. Buso, M. Citron, M. Corradim, and R. Pierobon: "Performance evaluation of a schottky SiC power diode in a boost PFC application", IEEE Trans. Power Electron., Vol.18, No.6, pp.1249-1253 (2003)

(8) R.W. De Doncker, D.M. Divan, and M.H. Kheraluwala: "A three-phase softswitched high-power density dc/dc converter for high-power applications", IEEE Trans. Ind. Appl., Vol.27, No.1, pp.63-73 (1991)

(9) M.H. Kheraluwala, R.W. Gascoigne, and D.M. Divan: "Performance characterization of a high-power dual active bridge dc-to-dc converter", IEEE Trans. Ind. Appl., Vol.28, No.6, pp.1294-1301 (1992)

(10) H. Akagi: "The next-generation medium-voltage power conversion circuits using ultra-low loss, high-speed power switching devices", JIASC 2003 , Vol.1, pp.183-186 (2003) (in Japanese) 赤木泰文:「超低損失・高速パワーデバイスの使用を前提とした次世代 高圧電力変換回路」, 平 15 電気学会産業応用部門大, Vol.1, pp.183-186
(2003)

(11) N. Okada: "Control of loop distribution network and result", The Paper of Technical Meeting on Power Systems Engineering, IEEJ, PSE-00-2, pp.212 (2000) (in Japanese)

岡田有功：「ループ配電系統の制御と効果」, 電気学会電力系統技術 研資, PSE-00-2, pp.2-12 (2000)

(12) P.W. Hammond: "A new approach to enhance power quality for medium voltage ac drives," IEEE Trans. Ind. Appl., Vol.33, No.1, pp.202-208 (1997)

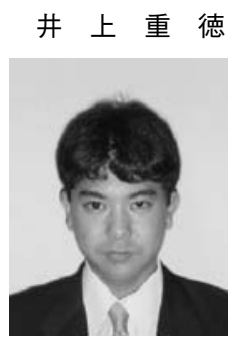

（学生員） 1979 年 1 月 29 日生。 2004 年 3 月東 京都立大学大学院工学研究科修士課程電気工学専 攻修了。同年 4 月, 東京工業大学大学院理工学研 究科電気電子工学専攻博士後期課程入学, 現在に 至る。次世代半導体電力変換回路に関する研究に 従事。

赤 木 泰 文 (正員) 1951 年 8 月 19 日生。1979 年 3 月東京工 業大学大学院電気工学専攻博士課程修了。工学博

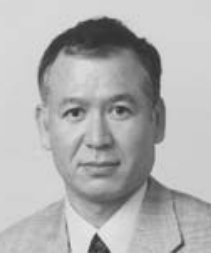
士。長岡技術科学大学助手 - 助教授, 岡山大学教 授を経て, 2000 年 1 月東京工業大学教授。パワー エレクトロニクスの研究に従事。電気学会論文賞 を 4 回, IEEE IAS/PELS Transactions Prize Paper Award 4 回, IEEE IAS Committee Prize Paper Award を 9 回受賞。1996 年 IEEE Felow。1998 年 IEEE IAS/PELS Distinguished Lecturer。2001 年 IEEE William E. Newell Power Elecronics Award。2004 年 IEEE IAS Outstanding Achievement Award。 